\title{
Pogrom or Collective Violence Against Jews from a Diversified, Interdisciplinary Research Perspective (Some Initial Notes)
}

\author{
Jacek Chrobaczyński \\ iD https://orcid.org/0000-0001-7896-2494 \\ (Pedagogical University in Krakow, Poland) \\ e-mail: chrobaczynski@poczta.onet.pl
}

Pogrom again... Conscience is asleep

Samuel Hirschhorn

To give a short review of this just released outstanding and robust publication is impossible, considering its statistics alone. But most importantly, when we consider the subject-matter defined as "pogrom/pogroms," "anti-Jewish pogrom" or "collective violence against Jews." This research project and, most importantly, this publication complement distinguished earlier works on the subject. They arouse not only admiration but, seen from various perspectives, also controversy or, sometimes, are even perceived as instances of ideological or quasi-historical (non-academic) malice. For Pogroms... is a robust work and the result of efforts by numerous researchers. Having read it with utmost attention, I perceive it as belonging to a series of recent research and publication events, such as Grabowski's Hunt for the Jews (2013), Grabowski and Engelking's edited volume Dalej jest noc (2018), Tokarska-Bakir's Pod klątwa (2018), publications by Adam Puławski, and the like. Therefore, Pogroms ... is an important complement or supplement to this body of literature, providing reliable knowledge and an interdisciplinary perspective in Polish historiography, ${ }^{1}$ adopted to address a difficult and often ambiguous issue that is frequently an object of manipulation, verification, and worse. All these elements make it a significant scientific, publishing, intellectual and educational event, in that order. Undoubtedly, as the work is read, the scope of its functions will expand.

I have mentioned the numbers behind this project, so here are just a few:

1. Four robust volumes, as mentioned above (see Footnote 1),

${ }^{1}$ The object of this review is Pogromy Żydów na ziemiach polskich w XIX i XX wieku [Anti-Jewish pogroms on Polish lands in the 19th and 20th centuries], Vol. 1, Literatura i sztuka [Literature and art], ed. Sławomir Buryła, Warszawa 2018; Vol. 2, Studia przypadków (do 1939 roku) [Case studies (until 1939)], ed. Kamil Kijek, Artur Markowski, and Konrad Zieliński, Warszawa 2019; Vol. 3, Historiografia, polityka, recepcja spoleczna (do 1939 roku) [Historiography, politics, social reception (until 1939)], ed. Kamil Kijek, Artur Markowski, and Konrad Zieliński, Warszawa 2019; Vol. 4, Holokaust i powojnie (1939-1946) [Holocaust and the post-war period (1939-1946)], ed. August Grabski, Warszawa 2019. 
2. In total: Vol. 1 - 462 pages, Vol. 2 - 470 pages, Vol. 3 - 425 pages, Vol. $4-671$ pages, which equals 2,028 pages,

3. Five volume editors,

4. Eighty-eight original texts and slightly fewer authors (60), as some of them have contributed two or three texts,

5. An outstanding number of footnotes, which are often - to use Leszek Kołakowski's term - "mini-lectures." Not only do they provide sources and bibliographic information, but they are very erudite and educational as well,

6. It supplements facilitating reading: lists of abbreviations, summaries and indexes of persons in every volume,

7. Presents extensive iconographic documentation,

8. My personal comment on reading: four months of attentive reading, rereading, pondering, nearly 80 pages of handwritten notes; a very interesting and bizarre experience in itself. Notes for further use.

The above statistics in themselves are quite impressive. And yet, studying these texts is another matter, one related to time and structure, sometimes similar in terms of methodology (introduction, definitions, analysis of the problem, conclusions). The chronology, too, is absorbing, in particular the dividing lines between the end of the 19th century (with references to earlier events such as the Warsaw pogrom of 1881) and the Kielce pogrom of 4 July 1946. Concepts, definitions, controversies, sometimes intellectual and methodological conflicts - these are not easy to process, either.

Therefore, the perspectives of the views, analyses, and perceptions differ between the four volumes here and there, and it all becomes controversial: the time of partitions and the pogroms in the Russian part of the Empire, but not only in the Kingdom (Kishinev, Odessa, etc.); the turning point of 1918 and its consequences, in particular the emergence of the Polish state (a new map of Europe after the First World War, the fall of empires, the turning point of 1917 in Russia) and its wobbly beginnings, with strong and long-lasting anti-Semitism in the background (including that of the army of General Haller, actively involved in attacks on Jews). The Second World War and German occupation (1939-1945) and the "post-war time" are defined slightly differently (although with some references to later times, such as the "dry pogrom" of March and after March 1968) than they are by Tony Judt, for example. The end point - the disgraceful Kielce pogrom - a sign of the times, not only of the place, as similar events were observed elsewhere around Poland, such as the so-called "wagon operation."

Volume one is an obvious exception here, with a clear and consciously ordered structure and solid chronology, sometimes only in the background but well-founded in time and space. The authors analyze the presence of anti-Jewish pogroms in literature and art: its permanence and influence, its contribution to the system of values, to remembrance and post-remembrance and, ultimately, to education. Perhaps this volume, with its very special nature, should close and not open the series? I have an impression that it may be quite confusing for some readers, particularly the specialized contexts found here, such as the analysis of a poem, of a photograph, a piece of art, and the language of diversified period texts. This is a highly erudite part created by authors of various specializations, including cultural ones. Naturally, they follow the main thread, namely the pogroms, but in the course of the analysis they enter areas which have little or nothing to do with 
history, but rather with art, existentialism, aesthetics, literary studies, and more. This is not common knowledge, nor is it the knowledge taught in schools, which, in the longer run, could facilitate the perception of a grown-up reader. Yet, the issue of "moving" the volume to the end of the series is just a remark, an educational reflection, and by no means a necessity.

The publication of the series was preceded by an extensive research project which could be described as "history told" (Vol. 1, p. 7), but also as "history known and unknown" (ibid). The project was carried out by prominent research centres: the Tadeusz Manteuffel Institute of History of the Polish Academy of Sciences (PAN), the Institute of History of the University of Warsaw, the University of Warmia and Mazury, and the Museum of the History of Polish Jews POLIN. Yet, the authors of the texts originate from a wider circle of academic research institutions. This is important, for, as the editor of Vol. 1 distinctively points out in its very first sentence: "The problem of pogroms has never been analyzed from the perspective of history or social or political science, alone. It has always been a part of projections on national identity, self-identification, the problem of guilt, responsibility, settling accounts with the past."

These are not all the components that need to be mentioned, as I would add consciousness, perpetration, complicity, and "rectification" of falsehoods and lies, of manipulation at various points in history (see the footnotes), and more. These are also the contexts of memory and multi-generational post-memory, or memory passed from one generation to another. Serving as a lens for this passing on of memory is education through organized and non-organized systems, in various fields and on various subjects, including religion. All this is presented against a diversified dynamics of historical time: the partitions, independent Poland, war and occupation, and the short "post-war time" ending in 1946. This is not easy, yet it confirms the observation, characteristically enough found in the majority of the texts, a reference to sources and to solid, reliable, objective, and validated analysis. True, there are also theses necessitating verification of current erroneous notions, of "knowledge" which simply contradicts reliable sources and research methods. And when the picture is supplemented by a literary and artistic context, it offers a kind of a universum, still with numerous questions, with necessary or even indispensable discourse, reflections, sometimes in the form of a snapshot, but also in the context of the "here and now."

This last issue, the "here and now," is rich and controversial, sometimes dynamically emerging in the discourse or propaganda, often brutal in many aspects, ambiguous, usually outside the scope of academic knowledge - see, for an example the so-called "politics of history" - but it also reflects the very important independent views of the authors of this robust publication, complementing it.

This universum does not only come from a Polish-Polish perspective. In many areas it also offers subjectified Jewish, Jewish-Jewish, Jewish-Polish and Polish-Jewish perspectives (with elements, or rather traces of, Russian or Galician traits). These perspectives are not only of the victims, but also of literature or art, of a lyrical subject, a totem, not of the symmetrism, but the integrity, although - from the point of view of research one can easily spot in them both the language of "an alien" and about "an alien," the language of exclusion and hateful hostility. Yet, there is also the language of a victim, of a poet and artist who sees it through his or her artistic perspective, with a reflex of 
education or identity, or sometimes even revolt or "racket." For, in the background, there is always the dynamics of the historical process, the dynamics of continuity and change of generations, political systems, a reflex of passing down, micro and macro experience, case study and, sometimes, even a study of synthesis and a quite extensive one. And unfortunately, also, the dynamics of political/ideological and religious use are not really in the pursuit of a good cause or message.

But the four volumes are not, in my opinion, a synthesis of the phenomenon. They are a multidimensional case/affliction, a hallmark, or often a case study of me, him, us, father, mother, family, community, and so on, as well as a message for future synthesis and an important set of guidelines. It is placed within a certain network of interrelations, already highlighted here, between Poles and Jews, presented against a Russian, Soviet, German, Ukrainian (among others) background of presence, relations, participation, and co-participation. It encompasses public officers and undeniably, already defined in the literature on the subject, typical elements of such research: perpetrators-victims-witnesses. And there is the source-based narration of memory, image, poem, story, and press article.

An important thesis serves as a link connecting all texts: "the chain of pogrom tradition" as a kind of "phenomenon" present over a considerable period of time. It was a continuous phenomenon, not an accidental one. And, regrettably, it was a "chain" of actions as well, with an important characteristic feature: the pogrom(s) was/were directed against Jews, a minority, and the attacking party was the majority: in many aspects diversified Polish communities, mostly Polish ones, which is highlighted. Not foreign but Polish communities, particularly after 1918. Quite significant is the fact that in smaller towns, where Jews were the largest national communities, not even a single attack (or pogrom) against a Polish statistical minority had been ever recorded. This is an important characteristic: Polish anti-Jewish pogroms. It must not be ignored. Moreover, the phenomenon was not marginal nor incidental, nor accidental. Regrettably, the phenomenon was rather common in the perspective of historical time, of social history, which is so overt in this research. And its perceptible scale, confirmed by sources, can be easily defined as massive, and not as incidental or exceptional.

There are still many questions waiting to be asked, thoroughly examined, and reliably answered. And although the ambivalent discourse has been recently approached in various ways, such as in the Jedwabne case, I think we have lost this discourse, despite the broad spectrum of research, narration, and the discourse itself. We have lost it in terms of civic and social attitudes and in terms of identity. We have lost it as a responsible civic society. Because only accuracy in approaching a historical process as a whole (including events that were bad, unpleasant, hostile, etc.) and acceptance of the outcomes of the research creates a picture free of manipulation, rage, falsehood, or even sometimes "fetish." And all this against the background of the consolidated/ever consolidating myths about Jews, regarding blood, matzah, the kidnapping of children, and more. It holds evidence not only in the past, but also in the present "traditions," utterances, actions, vile language, in the custom of "hitting a (an effigy of a) Jew" as an act of allegedly Christian "brotherly love." It is a kind of a wall which in an anti-Jewish, anti-Judaic and anti-Semitic attitude isolates huge areas and social groups, which continues to the present day. We can see that because we (still) have independent media. And because 
we have reliable research, like this four-volume publication and numerous others, which is often stigmatized by the "true Poles," "true patriots," and "true Catholics." Unfortunately, we also lack the common assumption, a spark which would ignite a deeper reflection, thought, consideration: Why did it happen in the past and why is it happening today? There is no time, no need, no sense of duty - apart from the very few instances, mentioned particularly in volume one, of stopping in the face of helpless victims, fellow citizens, killed also by their Polish fellow citizens. A reflex, also expressed in artistic forms, literary work, art, and so on.

The project that produced these four volumes was carried out in 2013-2016 in the Institute of History of the University of Warsaw, "with support of the National Programme for the Humanities [Narodowy Program Humanistyki] (Vol. 1, p. 17). The head of the project was Artur Markowski, PhD, supported by Prof. Sławomir Buryła and August Grabski, PhD. Members of the research team originated from ten different countries, with Poland predominant. The purpose of the project was defined by the authors as follows: "to describe the instances of anti-Jewish violence, but also to analyze the attitudes of, inter alia, the Catholic Church, political parties, and the public" (Vol. 1, p. 17). Having read the publication one can easily say that the objective so defined has been achieved. This does not mean, however, that there will be no discourse, comments, or pointing out of controversies. But as a whole, it is an outstanding work, and an important one, as well. Perhaps some parts of it, or maybe even the whole series, should be translated into foreign languages.

Each volume is a true research gem, even though sometimes it presents quite controversial theses that I wish to highlight, demolishing earlier patterns or standards of thinking, superficial narrations: often political and often aimed at conveying a certain message, containing a considerable amount of propaganda, lies, mystification, and religious misunderstandings/misinterpretations. The authors revise considerable amounts of superficial knowledge, provide well-documented analyses, and define new research fields, using precisely structured sequences of questions or hypotheses/theses.

This is why this project is so inspiring. Yet, although the term is frequently used, particularly in the prefaces to the volumes, this is not a four-volume monograph and nor is it a synthesis. And the reason for that is not the number of texts, often of contributory or auxiliary nature, although well founded in source materials and historiography, but the fact that each of them is a manifestation of authorial autonomy in terms of the introduction and conclusions. They all have introductions (hence the frequent repetitions and close analyses in various texts), and they have the main thread defined, but not in the monographic sense. These are rather the authors' original, autonomous, concise syntheses of problems, issues, and contexts. Although certainly they are not like pigeonholes, separated from one another, they share the same location. Frequently, these are pioneering texts, touching upon phenomena not previously discussed in the literature on the subject. But let me repeat: this is not a monograph, but rather an introduction to such an approach. The future problem synthesis (defined in the title of the research project) versus the published volumes is a very good preparation for a monographic synthesis. We have seen similar examples in literature.

However, shorter texts, case studies, and micro and macro perspectives - important in social history, and in a broader cultural context - which provide thorough auxiliary 
analyses or guidelines, exploring many problems, can, apart from being research materials, also serve as a solid educational guideline. They can be used in schools (shorter texts), in more extensive education, in the education of teachers, in media, in the education of citizens or, perhaps, even of "football hooligans," "leading actors" burning effigies of Jews, hanging portraits on gallows, and so on, and so forth... This is also a good handbook for educating clergymen as well as local and state officials in places still bearing traces of former presence of legitimate citizens of Poland who, however, did not enjoy equal rights with the citizens-Poles, who were "aliens," "others," "strangers," "excluded," "exiled," residents of ghettos, persecuted for having survived the Holocaust and going back to their houses and workshops (not "post-Jewish" but still "Jewish"), to their place on Earth. Coming back home, at last.

$$
* * *
$$

Summing up, it is an important contribution - robust and distinctive, solid in every aspect - to the analysis of the historical period starting at the end of the 19th century, cutting across the early 20th century, the reborn Polish state, the period of World War II and occupation between 1939 and 1945, the so-called PKWN-Poland just after the end of the war, People's Poland, ending in the Polish People's Republic established in 1952. This is also an important contribution in the discussion on the part of the historical process that falls within the scope of social history: exploring attitudes, behaviors, strategies of seeking help, but also strategies of violence, unlawful killing, and involvement in acts of hatred and hostility. Undoubtedly, this is a true phenomenon, but, naturally, there are also positive examples of Polish-Jewish and Jewish-Polish relations, relationships, contacts, presence and absence. My attitude towards this differentiation is heterogeneous, on numerous levels: those of subject-matter, attitudes and behaviors, relations, consciousness and identity, but also of memory, post-memory and no-memory (oblivion), apart from politics and ideology or the already mentioned so-called politics of history. I can see many differences in this relation and its reversed reflection, shifted accents, and symmetrism, but also asymmetry.

The texts here are meant to address numerous problems and issues. The authors highlight important aspects of Polish-Jewish and Jewish-Polish relations by analyzing notions, making extensive use of all available historical sources. Still, volume one is a novelty which - apart from literary and artistic analyses - also points out that literary texts, press articles, language, drawings, photographs, and the like, are historical sources equally important as memories and recollections, personal accounts, "remembrance books," and so forth. And, more importantly, they are equally legitimate sources. But, like any other source, they require validation, verification and thorough analysis, particularly in the context of narration.

We have been given a unique publication, a result of efforts by many prominent researchers. A publication which is not easy to read and assimilate, but which, in my opinion, is a good introduction to a solid discussion, in various fields and in various contexts. It is an inspiring and thought-provoking piece of work. It is worth reading, and reading again, using it to return to numerous problems. It is worth spending considerable amount of time, to find out and to understand. 